\title{
STRATEGI PEMBELAJARAN DI ANTARA GURU TERHADAP SISWA DALAM KONTEKS MEMECAHKAN KESULITAN BELAJAR
}

\author{
Pudun Tadam*1 \\ ${ }^{1}$ Malaysia Evangelical Theological Seminary, Lawas, Malaysia \\ *puduntadam5649@gmail.com
}

\begin{abstract}
Strategic Learning involves Learning Strategies and Teaching Strategies that can help bring success to a student. The research objective answers the question: What is the meaning of a Learning Strategy? What is an Effective Learning Strategy? What are the Learning Strategies among Teachers against Students in the Context of Solving Learning Difficulties? The answer is: Learning strategies are the methods that will be selected and used by a teacher to deliver learning material that aims to make it easier for students to receive and understand learning material, which in the end can be mastered learning objectives at the end of learning activities.

Three aspects of effective learning strategies are: (1) Students Need Continuous Strategic Instruction. (2) Teachers Promote Self-Awareness in Metacognition in the Classroom. (3) Teachers Can Recognize and Understand Different Learning Profiles. Learning Strategies between Teachers and Students in the Context of Solving Learning Difficulties are: (1) learning difficulties manifested in classrooms, (2) difficulties demonstrated by students in classrooms, and (3) strategies to help students who have difficulty paying attention in class.
\end{abstract}

Keywors: Strategic Learning, teaching strategies, learning strategies, strategic instruction

\begin{abstract}
Abstrak
Strategic Learning melibatkan Strategi Pembelajaran dan Strategi Pengajaran yang dapat membantu membawa kejayaan kepada seorang mahasiswa. Tujuan penelitian menjawab pertanyaan: Apakah pengertian Strategi Pembelajaran? Bagaimanakah Strategi Pembelajaran yang Efektif? Bagaimanakah Strategi Pembelajaran di antara Guru terhadap Siswa dalam Konteks Memecahkan Kesulitan Belajar? Jawabannya adalah: Strategi pembelajaran adalah cara-cara yang akan dipilih dan digunakan oleh seorang pengajar untuk menyampaikan materi pembelajaran yang bertujuan untuk memudahkan peserta didik menerima dan memahami materi pembelajaran, yang pada akhirnya tujuan pembelajaran dapat dikuasainya di akhir kegiatan belajar. Tiga hal strategi pembelajaran yang efektif adalah: (1) Siswa Memerlukan Instruksi Strategi yang Berkelanjutan. (2) Guru Mempromosikan Kesadaran Diri dalam Metakognisi di Kelas. (3) Guru-guru Dapat Mengenali dan Memahami Profil Pembelajaran yang Berbeda. Strategi Pembelajaran di antara Guru terhadap Siswa dalam Konteks Memecahkan Kesulitan Belajar adalah: (1) kesulitan belajar dimanifestasi dalam bilik kelas, (2) kesulitan didemonstrasi oleh siswa dalam bilik kelas, dan (3) strategi-strategi untuk membantu siswa yang kesulitan perhatian di kelas.
\end{abstract}

Kata Kunci: Pembelajaran strategis, strategi pengajaran, instruksi strategis 
Excelsis Deo: Jurnal Teologi, Misiologi dan Pendidikan

2 | Vol. 4 No. 2 (Desember 2020) 



\section{PENDAHULUAN}

Sementara bahasa mendefinisikan kemanusiaan, literasi mendefinisikan peradaban. Maklum, buta huruf atau kesulitan dalam memperoleh keterampilan keaksaraan telah menjadi perhatian utama masyarakat teknologi. Perkiraan konservatif tentang prevalensi masalah keaksaraan akan menempatkan angka pada lebih dari satu miliar orang di dunia. Karena keseriusan masalah, penelitian dalam akuisisi literasi dan pemecahannya dilakukan dengan semangat dan ketekunan yang sangat besar oleh para ahli dari berbagai latar belakang seperti psikologi kognitif, ilmu saraf, linguistik dan pendidikan. Hal ini, tentu saja, telah menghasilkan banyak sekali data, dan akibatnya menjadi sulit untuk mengintegrasikan informasi yang berlimpah ini ke dalam sebuah badan yang koheren karena hambatan artifisial yang ada di antara berbagai spesialisasi profesional. ${ }^{1}$

Sebilangan siswa memberikan tantangan khusus kepada orang tua dan guru mereka karena ketidakkonsistenan dalam penalaran, pemecahan masalah, dan keterampilan dasar, dan kinerja akademis mereka secara keseluruhan. Mereka sering menunjukkan bakat luar biasa di bidang yang memerlukan penalaran dan pemecahan masalah, namun mereka berjuang dengan keterampilan hafalan seperti menghafal tabel perkalian, ejaan, dan decoding. Meskipun mereka dapat memperoleh nilai yang sangat baik untuk tugas kelas, mereka bekerja dengan buruk dalam situasi ujian yang lebih formal. Karena sebagian besar siswa ini sekarang terintegrasi ke dalam kelas pendidikan umum, setiap guru harus

${ }^{1}$ Rachel Schiff dan R. Malatesha Joshi (eds) Intervention in Learning Disabilities (AG Switzerland: Springer International Publishing, 2016), ebook. menghadapi tantangan dalam memenuhi keperluan anak-anak yang belajar secara berbeda. Selain itu, karena setiap siswa memiliki gaya belajar yang unik, guru dituntut untuk memenuhi berbagai keperluan pembelajaran di dalam kelas. Strategic Learning memberikan teknik pengajaran yang realistis dan dapat diakses untuk guru, pendidik khusus, dan profesional lainnya yang bekerja dengan siswa di tingkat sekolah dasar, menengah, dan awal. Strategi-strategi ini dapat membantu para guru untuk memahami berbagai profil pembelajaran siswa mereka dan menciptakan lingkungan kelas yang mendorong semua siswa untuk sukses.

Ruang kelas yang mendorong upaya, ketekunan, penggunaan strategi, orientasi tujuan, dan pengambilan risiko sering kali dapat memutus siklus negatif kegagalan yang dialami oleh siswa sehingga mengurangi perasaan rentan dan tidak berdaya mereka. Modifikasi kecil dalam budaya kelas seringkali dapat memberikan kesempatan bagi siswa untuk menyadari potensi akademis dan sosial mereka, serta mengurangi banyak kesengsaraan dan frustrasi yang tidak perlu. Penggunaan strategi yang efektif dapat meningkatkan motivasi, ketekunan, dan konsep diri dan akibatnya dapat meningkatkan keberhasilan akademik dan pembelajaran mandiri. Dalam penulisan ini, penulis memberikan gambaran umum tentang prinsip-prinsip yang mendasari tentang Strategic Learning sebagai kunci kejayaan seorang siswa.

Paris, Wasik dan Turner mendefinisi strategi sebagai pencerminan peran metakognitif dan pengaturan diri yang mereka mainkan dan menganggap strategi sebagai proses yang secara sadar dirancang 
untuk mencapai tujuan tertentu. ${ }^{2}$ Para peneliti membedakan strategi dari keterampilan, yang dipandang sebagai proses yang lebih otomatis dan tidak disadari. Namun, mereka mempertahankan bahwa ada hubungan yang erat antara keterampilan dan strategi dan bahwa strategi adalah "skills under consideration" dan dapat menjadi keterampilan ketika mereka "go underground". ${ }^{3}$ Skill merupakan proses pendidikan sebagai usaha penyaluran ilmu, melainkan proses pengubahan hidup berdasarkan kehendak Allah. Penguasaan pengetahuan hanyalah batu loncatan untuk menghasilkan perubahan hidup. ${ }^{4}$ Berkaitan hal tersebut, Harianto GP mengatakan bahwa cognitive function development efforts will have a positive impact not only on coqnitive itself, but rather the affective and psychomotor. There are two kinds of skills students need cognitive especially developed by teachers, namely: (1) strategies to learn to understand the content of the subject matter, (2) the strategy of asserting the importance of the subject matter and content of the application as well as absorb the moral messages contained in the material. ${ }^{5}$

Setiap keputusan dalam hidup dipengaruhi oleh learning. Learn (belajar) adalah perubahan tingkah laku berdasarkan pengalaman. Menurut teori ekonomi, pengambil keputusan ideal dijalankan melalui perhitungan yang rumit untuk

\footnotetext{
${ }^{2}$ Lawrence Erlbaum, Research and Global Perspectives in Learning Disabilities (Mahwah NJ: Lawrence Erlbaum Associates Pub., 2001), 112.

${ }^{3}$ Ibid., 113.

${ }^{4}$ Harianto GP, Pendidikan PAK (Yogyakarta: Andi, 2017), 25.

${ }^{5}$ Harianto GP, (2016), “Quality Learning Cooperative With Pattern Collaborative to Improve the Character", Jurnal Tekpen, 1(1), 43.
}

mendapatkan keputusan yang optimal, ${ }^{6}$ namun dalam praktiknya, orang biasanya belajar dengan mencoba-coba.

Apa yang mereka pelajari bergantung pada apa yang orang lain (guru, teman sekelas, orang tua) lakukan. Siswa yang berbeda belajar dari pengalaman mereka dengan cara yang berbeda. Pembelajaran yang berbeda ini gaya didasarkan pada tiga faktor adalah: Strategi, pengajaran, dan pembelajaran.

Strategic Learning didefinisikan sebagai "menggunakan evaluasi untuk membantu organisasi atau kelompok belajar dengan cepat dari pekerjaan mereka sehingga mereka dapat belajar dari dan menyesuaikan strategi mereka. Ini berarti mengintegrasikan evaluasi dan pemikiran evaluatif ke dalam pengambilan keputusan strategis dan membawa data tepat waktu ke meja untuk refleksi dan penggunaan".?

Berkaitan hal tersebut, maka Schumaker and Deshler mendefinisi a Strategic Learning adalah "pendekatan individu untuk suatu tugas. Ini mencakup bagaimana seseorang berpikir dan bertindak ketika merencanakan, melaksanakan, dan mengevaluasi kinerja pada tugas dan hasilnya. ${ }^{8}$ Strategic Learning berfokus pada pengajaran strategi siswa yaitu, metakognisi dan pola pikir, yang dapat mereka manfaatkan untuk meningkatkan kemampuan mereka untuk belajar. Pada

\footnotetext{
${ }^{6}$ https://www.researchgate.net/publication/ 50313189_Strategic_Learning_and_Teaching (diakses pada 25/9/2020).

${ }^{7}$ "Center for Evaluation Innovation",https://www.bsu.edu/about/administrativ eoffices/online-and-strategic-learning/about (diakses pada 21/9/2020).

${ }^{8}$ J.B. Schumaker \& D.D. Deshler, "Teaching adolescents to be strategic learners". Teaching Adolescents with Disabilities: Accessing the General Education Curriculum (Thousand Oaks, CA: Corwin Press, 2006), 121.
} 
akhirnya, tujuan pembelajaran strategis adalah untuk membantu siswa menjadi pembelajar seumur hidup yang mandiri yang dapat belajar secara efektif dalam lingkungan pembelajaran apa pun.

Solusi untuk menyelesaikan persoalan-persoalan tersebut dapat dijawan dalam pertanyaan berikut: Apakah pengertian Strategi Pembelajaran? Bagaimanakah Strategi Pembelajaran yang Efektif? Bagaimanakah Strategi Pembelajaran di antara Guru terhadap Siswa dalam Konteks Memecahkan Kesulitan Belajar?

\section{METODE}

Metode penulisan artikel ini adalah jenis artikel konseptual atau artikel hasil pemikiran (bukan artikel hasil penelitian) merupakan analisa pemikiran terhadap fenomena-fenomena masalah yang muncul. Selanjutnya bahwa Brown \& Campione mengatakan bahwa penulis meneliti bahanbahan literatur yang berkaitan dengan permasalahannya. Bahan yang dikumpulkan tentu saja berbagai hal adalah bahan-bahan yang mendukung dan menolak pemikiran yang sedang penulis kaji tetapi bahan mendukung yang berupa hasil penelitian atau artikel atau buku dapat digunakan dalam artikel konseptual. Artikel konseptual berbicara bukan sekadar kumpulan kutipan dari sejumlah artikel, tetapi memasukan memikiran kritis penulisanya. ${ }^{9}$

\section{PEMBAHASAN}

\section{Pengertian Strategi Pembelajaran}

Istilah seperti strategi pembelajaran, strategi pengajaran, dan pembelajaran

${ }^{9}$ A.L. Brown \& J.C. Campione (1986), "Psychological Theory and the Study of Learning Disabilities". American Psychologist, 41(10), 10591068. https://doi.org/10.1037/0003-066X.41.10.1059. strategis digunakan secara luas untuk menyiratkan bahwa pelajar dapat memilih prosedur khusus untuk menyelesaikan tugastugas tertentu. Strategi ini dapat membantu siswa meningkatkan kinerja membaca, menulis, matematika, dan pemecahan masalah mereka. Pentingnya pembelajaran strategis telah dibuktikan dalam hasil karya yang menunjukkan bahwa pelajar yang berhasil menggunakan strategi yang efektif untuk memproses informasi. ${ }^{10}$ Pembelajaran yang efektif terjadi ketika penerapan strategi pembelajaran khusus siswa berinteraksi dengan berbagai proses lain, termasuk pengambilan otomatis dari keterampilan dasar, perhatian yang tepat dalam situasi belajar, kesadaran diri, motivasi, dan konsep diri.

Instruksi strategis akan mencapai tujuan-tujuan berikut: (1) Siswa belajar bagaimana belajar daripada hanya belajar apa. Dengan kata lain, siswa mempelajari strategi yang mereka dapat menggeneralisasi di berbagai area konten dan tugas yang berbeda. (2) Strategi membantu siswa mulai memahami proses pembelajaran. (3) Strategi membantu siswa untuk melewati area kelemahan mereka dan untuk tampil di tingkat yang mereka mampu. (4) Strategi mempromosikan pemikiran yang fleksibel dan mengajarkan siswa pentingnya mengalihkan pendekatan mereka ke tugas yang berbeda. (5) Strategi mendorong pembelajaran mandiri. (6) Penggunaan strategi membantu siswa menjadi pelajar yang lebih efisien dan lebih efektif.

Strategi pembelajaran sangat penting untuk membantu siswa melewati area kelemahan mereka dan mengandalkan area kompetensi mereka. Oleh karena itu, kesediaan siswa untuk menerapkan strategi

\footnotetext{
${ }^{10}$ Ibid.
} 
pada tugasan kelas dan kerja rumah mereka bergantung pada sejauh mana mereka mengenali nilai strategi tertentu. Siswa perlu memahami profil dan keperluan belajar mereka sendiri sebagai pelajar dan untuk mengenali bagaimana dan mengapa strategi dapat membantu mereka mencapai keberhasilan akademis. Oleh karena itu, unsur penting untuk instruksi strategi yang sukses adalah kesadaran diri setiap siswa tentang profil kekuatan dan kelemahannya, serta strategi yang paling efektif untuk profil pembelajarannya. Siswa dengan kesulitan belajar sering kali tidak efisien sebagai pembelajar karena mereka memiliki kesulitan dalam memprioritaskan dan mengidentifikasi tema utama. Mereka sering kali terlalu fokus pada detail dan menunjukkan kesulitan organisasi utama, yang memengaruhi tingkat dan efisiensi mereka sebagai pelajar. Meskipun mereka mungkin mencapai tujuan yang sama dengan rekan-rekan mereka yang biasanya berprestasi, mereka sering berbeda dalam cara mereka mencapainya, seberapa cepat mereka sampai di sana, dan frustrasi yang mereka alami dalam perjalanan. Sama seperti laluan bulatan (rute bundaran) ke suatu tujuan dapat membuat frustasi karena sangat memakan waktu, demikian juga pembelajaran dapat membuat frustasi ketika prosesnya panjang dan sulit dan tujuan tidak dapat dicapai dengan mudah. ${ }^{11}$

$$
\text { Dari uraian di atas dapat }
$$
disimpulkan bahwa strategi pembelajaran adalah cara-cara yang akan dipilih dan digunakan oleh seorang pengajar untuk menyampaikan materi pembelajaran yang bertujuan untuk memudahkan peserta didik menerima dan memahami materi pembelajaran, yang pada akhirnya tujuan

\footnotetext{
${ }^{11}$ Lawrence Erlbaum, Research and Global Perspectives in Learning Disabilities, 111-130.
}

pembelajaran dapat dikuasainya di akhir kegiatan belajar.

\section{Strategi Pembelajaran yang Efektif}

Instruksi strategi eksplisit bermanfaat bagi semua siswa, tetapi lebih penting bagi siswa yang mengalami kesulitan belajar. Pengajaran strategis harus sistematis, sangat terstruktur, dan eksplisit, dan harus mencakup kesempatan bagi siswa untuk mengalami kesuksesan sebagai hasil dari penggunaan strategi tertentu. Pengajaran strategis sangat penting untuk mengajar semua siswa berbagai strategi yang lebih luas daripada yang mereka gunakan secara spontan. Siswa perlu diajari teknik khusus untuk mengatur dan merencanakan pekerjaan mereka, dan untuk menghafal, memprioritaskan, dan memeriksa diri, yang semuanya merupakan bahan penting dari kesuksesan akademis.

Beberapa metode instruksi strategis berbasis penelitian telah terbukti meningkatkan pembelajaran bagi siswa dengan kesulitan belajar dan dapat dengan mudah dimasukkan ke dalam kelas pendidikan umum. Metode ini meliputi: (1) Mengurutkan atau memecah tugas menjadi aktivitas singkat dan tugas komponen dengan petunjuk langkah demi langkah yang secara bertahap dihapus. (2) Pengulangan, merevisi, dan praktik dalam menerapkan strategi tertentu. (3) Memantau dan menyesuaikan tingkat kesulitan dan tuntutan pemprosesan tugas. (4) Berpikir keras pemodelan penyelesaian tugas yang berhasil. (5) Membuat kelompok-kelompok kecil di kelas bagi siswa untuk menerapkan strategi dan untuk mendiskusikan keberhasilan dan kesulitan mereka dengan rekan-rekan mereka. (6) Melibatkan guru pendidikan khusus, tutor, dan orang tua dalam instruksi strategi. (7) Menciptakan 
iklim kelas di mana semua siswa menghargai strategi dan mendiskusikan strategi baru setiap hari. (8) Memberi siswa kesempatan yang sering untuk mempraktikkan strategi yang telah mereka pelajari dan menerapkan strategi ini untuk tugas baru. (9) Menyediakan sistem penggredan bertingkat supaya pelajar dinilai untuk menyelesaikan fasa kerja mereka yang berlainan dan bukan hanya produk akhir. Contohnya, dengan memecah gred menjadi gred komponen nota, garis besar, draf karya bertulis, dan produk akhir. ${ }^{12}$

Berikut adalah Prinsip-prinsip dari Instruksi Strategi berbasis Kelas adalah: (1) Setiap siswa belajar secara berbeda dan memiliki profil belajar yang unik. (2) Setiap siswa perlu memahami profil kekuatan dan kelemahannya sendiri. (3) Setiap siswa harus memahami pentingnya menggunakan strategi. (4) Setiap siswa perlu memahami pentingnya kerja keras, ketekunan, dan penggunaan strategi untuk keberhasilan akademik. (5) Setiap siswa perlu memahami bahwa strategi memerlukan lebih banyak usaha pada awalnya, tetapi menghasilkan pekerjaan yang akurat dan efisien dari waktu ke waktu. (6) Setiap siswa harus mengembangkan tujuan pembelajaran yang dipersonalisasi dan rencana untuk menggunakan strategi khusus untuk mencapai tujuan tersebut. (7) Setiap siswa membutuhkan kesempatan untuk berhasil sebagai hasil dari penggunaan strategi khusus dan untuk mengenali hubungan antara penggunaan strategi khusus dan peningkatan akademis. (8) Setiap siswa membutuhkan kesempatan untuk mengekspresikan kekuatannya dan untuk mengembangkan sebuah "Islands of

\footnotetext{
${ }^{12}$ Harris et al., 2002; Meltzer \& Montague, 2001; Swanson, Hoskyn, \& Lee, 1999.
}

competence" (pulau kompetensi) $^{13}$ saat menggunakan strategi. (12) Semua siswa perlu merasa didukung dan terhubung di sekolah sehingga ruang kelas dan sekolah mereka menumbuhkan rasa kepemilikan dalam komunitas tempat di mana mereka merasa dihargai.

\section{Siswa Memerlukan Instruksi Strategi yang Berkelanjutan}

Setiap tahap gred menandai perubahan dalam kurikulum, pengaturan, harapan, dan perkembangan kognitif dan sosial setiap siswa. Profil belajar siswa tidak statis, tetapi sering berubah sebagai fungsi dari kecocokan atau ketidaksesuaian antara kekuatan dan kelemahan spesifik siswa dan tuntutan kelas, guru, dan kurikulum. Beberapa siswa yang tidak menunjukkan kesulitan awal sekolah mungkin tiba-tiba tersungkur ketika tuntutan kelas berubah dan memerlukan koordinasi berbagai subketerampilan dan strategi. Akibatnya, kesulitan belajar yang sebelumnya tidak disadari dapat menjadi nyata di kelas-kelas berikutnya, ketika strategi kompensasi yang sebelumnya berhasil kini tidak lagi efektif.

Masa transisi kritis dalam kurikulum (kelas satu, kelas empat, sekolah menengah pertama, sekolah menengah atas, dan perguruan tinggi) dapat menjadi masalah khusus bagi siswa. Masing-masing transisi ini sesuai dengan tuntutan organisasi yang meningkat dan pengenalan tugas yang memerlukan koordinasi dan integrasi berbagai keterampilan dan strategi. Misalnya adalah: misalnya, tugas menulis yang kompleks, laporan buku, dan tes pilihan ganda. Guru kelas dapat membantu

\footnotetext{
${ }^{13}$ Robert Brooks, "Islands of competence", https://massappleseed.org/wpcontent/uploads/2018/01/drbrooks_studentmindset_chapter.pdf.
} 
siswa untuk lebih berhasil dengan mengajarkan strategi yang efektif dan, jika perlu, mengubah tuntutan kelas untuk mengakomodasi tingkat dan gaya belajar siswa yang bervariasi.

\section{Guru Mempromosikan Kesadaran Diri dalam Metakognisi di Kelas}

Guru dapat mempromosikan kesadaran diri dan metakognisi di kelas. Apabila seseorang itu sedar tentang apa yang dipikirkan maka mudah baginya mengawal tindakan yang diambil seterusnya. Instruksi strategi bisa berhasil hanya jika siswa mau dan mampu menghasilkan strategi dan menghargai dan mengambil kepemilikan dari strategi yang diajarkan. Siswa perlu memahami bagaimana mereka belajar dan bagaimana strategi spesifik dapat membantu mereka untuk meningkatkan akurasi dan efisiensi mereka. Oleh karena itu, kesadaran diri penting untuk instruksi strategi yang berhasil, yang bergantung pada pemahaman siswa tentang profil pembelajaran mereka dan kemauan mereka untuk melakukan upaya yang diperlukan untuk menerapkan strategi tertentu pada tugas-tugas pembelajaran yang berbeda. Kesadaran diri juga penting karena peningkatan waktu kerja yang terlibat pada awalnya saat siswa mempelajari pendekatan baru. Proses ini seringkali lambat, dan siswa memerlukan keberhasilan sebelum mereka menggeneralisasikan strategi yang telah mereka pelajari ke berbagai tugas dan jenis pekerjaan.

Meskipun siswa mencapai akurasi yang lebih besar melalui penggunaan strategi tertentu, mereka mungkin pada awalnya mengorbankan kecepatan dan efisiensi. Penggunaan strategi sistematis, bagaimanapun, memastikan bahwa siswa menjadi semakin efisien dari waktu ke waktu, dan ini mengakibatkan berkurangnya waktu kerja. Misalnya, ketika siswa mulai menggunakan strategi perencanaan untuk mengatur pekerjaan tertulis mereka, waktu yang dihabiskan untuk menggambar peta dan jaring atau mengembangkan catatan tiga kolom (lajur) dapat membuat siswa merasa bahwa mereka menghabiskan lebih banyak waktu untuk pekerjaan tertulis mereka. Namun, penggunaan strategi ini menghasilkan produk tertulis yang lebih teratur dan memerlukan lebih sedikit pengeditan. Akibatnya, pekerjaan tertulis pada akhirnya memerlukan lebih sedikit waktu bagi siswa dan menghasilkan produk tulisan yang lebih baik dan nilai yang lebih tinggi. Oleh karena itu, tantangan utama bagi guru adalah memastikan bahwa siswa yang menerapkan strategi khusus mencapai keberhasilan yang cukup cepat. Keberhasilan dalam kelas meningkatkan kemauan siswa untuk menggunakan strategi khusus dan membuat upaya untuk menggunakan strategi yang sama dalam situasi yang berbeda, komponen inti dari generalisasi.

\section{Guru-guru Dapat Mengenali dan Memahami Profil Pembelajaran yang Berbeda}

Guru dapat menggunakan metode penilaian informal untuk memperoleh pemahaman tentang mengapa dan bagaimana siswa tertentu mungkin bergelut (struggle). Gagasan tentang guru sebagai asesor (penilai) menjadi semakin populer seiring dengan berkembangnya metode Assessment for Teaching. ${ }^{14}$ Baik observasi dan berbagai metode penilaian berbasis kelas dapat digunakan untuk mengevaluasi

\footnotetext{
${ }^{14}$ Meltzer, 1993a, 1993b; Roditi, 1993.
} 
bagaimana siswa mempelajari materi yang diperlukan dan seberapa efektif mereka mempertahankan dan mengakses pengetahuan. Teknik penilaian berbasis kinerja dan metode penilaian portofolio juga menjadi semakin luas untuk penilaian kelas. ${ }^{15}$ Kombinasi metode penilaian informal ini dapat memberikan informasi yang berguna kepada guru yang terampil tentang kekuatan dan kelemahan kebanyakan siswa.

Beberapa siswa menunjukkan profil pembelajaran yang sulit untuk dipahami tanpa informasi penilaian yang diperoleh dari tes formal atau ukuran penilaian berbasis kelas. Pengujian neuropsikologis dan pendidikan formal sering kali memberikan informasi penting tentang gaya belajar siswa dan membantu guru untuk memahami mengapa siswa tertentu berjuang (struggle) di kelas. Namun, penilaian ini tidak dapat memberikan semua jawaban. Penting untuk disadari bahwa penilaian dibatasi jika hanya memberikan skor dan setara tingkat kelas. Lebih lanjut, tes berorientasi produk tidak menjelaskan bagaimana siswa belajar dan mengapa siswa mengalami kesulitan. Penilaian sangat membantu jika ia berorientasikan proses, fokus pada bagaimana siswa belajar, dan memberikan rekomendasi pendidikan khusus yang dapat dilaksanakan dalam suasana kelas.

\section{Strategi Pembelajaran di antara Guru terhadap Siswa dalam Konteks Memecahkan Kesulitan Belajar}

Tidak ada profil akademis tunggal yang mencirikan semua siswa dengan kesulitan belajar yang mungkin memiliki kelemahan dalam memori, bahasa, persepsi

\footnotetext{
${ }^{15}$ Fuchs \& Fuchs, 2002.
}

pendengaran, persepsi visual, kecepatan pemrosesan, atau proses eksekutif. Beberapa adalah pembaca dan pengeja yang buruk. Yang lain mengalami kesulitan dengan ekspresi tertulis atau lisan. Yang lain lagi tidak bisa menghafal fakta matematika. Beberapa siswa dengan kesulitan belajar mungkin memiliki keterampilan organisasi yang lemah dan mungkin tidak menentu dalam menyelesaikan tugas kerja rumahnya. Siswa dengan kelemahan perhatian mungkin memiliki kesulitan akademis dan sosial. Karakteristik yang dimiliki oleh semua siswa ini adalah bahwa, meskipun kemampuan intelektual mereka rata-rata hingga di atas rata-rata, mereka mengalami keterlambatan dalam keterampilan membaca, menulis, matematika, menyimak, dan berbicara. Dengan kata lain, ada perbedaan yang signifikan antara kemampuan dan prestasi. Sebagian besar siswa ini memiliki kombinasi kesulitan belajar, yang manifestasinya dapat sangat bervariasi.

Banyak siswa dengan kesulitan belajar juga mengalami kesulitan perhatian dan mungkin menunjukkan impulsivitas, distractibility, dan aktivitas motorik yang berlebihan. Para siswa ini mungkin mengalami kesulitan organisasi, memiliki masalah tetap pada tugas, dan mengalami kesulitan berkonsentrasi dalam situasi kelompok. Karakteristik perilaku ini sering mengarah pada diagnosis gangguan defisitperhatian (gangguan) hiperaktif.

Yang paling sulit dipahami dan membingungkan guru adalah siswa yang menunjukkan masalah perhatian tetapi tidak terlalu aktif. Siswa-siswa ini sering kali mudah terganggu, tidak teratur, atau impulsif, dan menunjukkan keterampilan pemantauan diri yang buruk. Terkadang, mereka hanya fokus pada tema global dan 
mengabaikan detailnya. Di lain waktu, mereka terlalu fokus pada detail dan kesulitan mengidentifikasi masalah global. Akibatnya mereka menjadi bingung ketika terlalu banyak informasi yang disajikan. Mereka juga sangat mudah terganggu dan tampak seperti melamun sehingga instruksi sering kali perlu diulangi. Akibatnya, tugas yang memerlukan pengorganisasian dan penentuan prioritas mungkin sulit bagi mereka. Karena mereka tidak memiliki masalah perilaku dan kesulitan mereka seringkali tidak kentara, mereka dapat diabaikan atau salah didiagnosis. Akibatnya, masalah akademik mereka mungkin salah dikaitkan dengan motivasi rendah, kurangnya usaha, atau kemampuan intelektual yang lebih rendah daripada kesulitan perhatian mereka.

Untuk siswa dengan kesulitan belajar dan perhatian, instruksi strategi perlu eksplisit, terstruktur, dan rekursif. Penggunaan strategi yang sering di seluruh area konten dan dalam berbagai pengaturan (misalnya, rumah, sekolah) memungkinkan konsolidasi dan generalisasi. Penggunaan strategi dan praktik harus diperlukan untuk tugas di dalam kelas dan pekerjaan rumah. Pengajaran kelompok kecil dalam kelas yang lebih besar seringkali dapat memberikan kesempatan untuk praktek dan penguasaan strategi, sedangkan instruksi berbasis kelas kelompok besar memastikan bahwa generalisasi terjadi. Tujuannya adalah untuk memastikan bahwa siswa belajar menggunakan strategi secara fleksibel dalam domain yang berbeda dan dengan tugas yang berbeda.

\section{Kesulitan Belajar Dimanifestasi dalam Bilik Kelas}

Kesulitan belajar yang dialami siswa disebabkan sebagai berikut: (1) mungkin bisa memproses informasi secara unik, (2) dapat memproses informasi dengan lambat.

\section{Kesulitan Didemonstrasi oleh Siswa dalam Bilik Kelas}

Kesulitan didemonstrasi oleh siswa dalam kelas sebagai berikut: (1) menunjukkan perbedaan antara cara-cara di dalam kelas dan ujian kinerja, (2) lambat untuk bersuka rela, mengalami kesulitan dengan tugasan yang berjangka waktu, (3) mungkin memiliki kelemahan dalam pemprosesan bahasa, (4) mungkin mengalami kesulitan mengingat informasi hafalan karena kelemahan dalam memori otomatis, (5) mungkin tidak boleh membangun strategi yang efisien dan efektif untuk menyelesaikan tugas, (6) mungkin mengalami kesulitan untuk beralih secara fleksibel di antara pendekatan yang berbeda, (7) tidak boleh meninggalkan strategi yang tidak efisien atau tidak efektif, (8) mungkin berjuang (struggle) untuk memprioritaskan dan untuk fokus pada detail yang menonjol, (9) mungkin tidak teratur atau mungkin menggunakan rute pemrosesan yang berbeda untuk mengatur informasi, (10) mungkin kesulitan mengoordinasikan strategi yang diperlukan untuk belajar secara efektif, (11) tidak menyadari kegunaan dari strategi perencanaan khusus dan pemeriksaan, (12) mungkin impulsif dan mungkin tidak secaraspontanmerencanakan pekerjaan mereka, (13) mungkin tidak mengoreksi diri secara spontan, (14) menunjukkan kesulitan mentaati arahan, nampak tidak memberi perhatian, (15) berjuang (struggle) untuk mengingat formasi huruf, fakta matematika, hari dalam seminggu, bulan dalam setahun, (16) tampaknya tertinggal dari orang lain dan lebih lambat dalam menguasai strategi belajar; kesulitan sering menutupi penalaran 
konseptual dan pemecahan masalah superior siswa, (17) mengalami kesulitan menyesuaikan diri dengan guru baru dan situasi baru, (18) dapat secara konsisten menyelesaikan masalah dengan cara yang sama meskipun ada instruksi dalam strategi alternatif, (19) mungkin berbicara tentang masalah; tidak bisa meringkas; memiliki keterampilan belajar yang buruk, strategi penyusunan yang buruk, pemahaman bacaan yang buruk, (20) memiliki tas buku yang berantakan, tulisan tidak rapi, tidak siap untuk kelas, (21) menunjukkan kinerja tugas yang tidak konsisten (misalnya, skor 100\% pada tes ejaan terstruktur dengan satu kata yang didiktekan, tetapi salah mengeja katakata yang sama ini dalam konteks penulisan kreatif), (22) tidak gunakan strategi pra-baca atau pra-penulisan, tidak mengedit, (23) tidak teratur, sulit untuk mengatur waktu mereka, dan (24) Cuai dalam matematika, ejaan, dan menulis.

Strategi-strategi untuk Membantu Siswa yang Kesulitan Perhatian di Kelas

\begin{tabular}{|c|c|c|}
\hline $\begin{array}{l}\text { Kesulitan } \\
\text { siswa } \\
\text { bermasa- } \\
\text { lah } \\
\text { perhatian } \\
\text { alami }\end{array}$ & $\begin{array}{l}\text { Bagaimana } \\
\text { siswa } \\
\text { mendemon- } \\
\text { strasi } \\
\text { kesulitan ini } \\
\text { dalam bilik } \\
\text { kelas }\end{array}$ & $\begin{array}{l}\text { Strategi } \\
\text { untuk } \\
\text { membantu } \\
\text { siswa yang } \\
\text { bermasalah } \\
\text { perhatian }\end{array}$ \\
\hline $\begin{array}{l}\text { Mudah } \\
\text { bingung }\end{array}$ & $\begin{array}{l}\text { Lamunan } \\
\text { (terganggu } \\
\text { oleh pikiran } \\
\text { batin) atau } \\
\text { memper- } \\
\text { hatikan suara } \\
\text { asing atau } \\
\text { rangsangan } \\
\text { visual di } \\
\text { ruang kelas }\end{array}$ & $\begin{array}{l}\text { Melakukan } \\
\text { kontak mata } \\
\text { dengan } \\
\text { siswa }\end{array}$ \\
\hline
\end{tabular}

\begin{tabular}{|c|c|c|}
\hline Impulsif & $\begin{array}{l}\text { Tidak } \\
\text { membuat } \\
\text { rencana } \\
\text { sebelum } \\
\text { memulai. } \\
\text { Memiliki } \\
\text { masalah } \\
\text { sosial karena } \\
\text { komen-tar } \\
\text { yang tidak } \\
\text { pantas. } \\
\text { Tampak cuai } \\
\text { dan lalai } \\
\text { terhadap } \\
\text { detail. }\end{array}$ & $\begin{array}{l}\text { Menyediaka } \\
\mathrm{n} \text { tempat } \\
\text { isti-mewa. } \\
\text { Ajarkan } \\
\text { strategi } \\
\text { perencanaan } \\
\text { dan } \\
\text { pemeriksaan } \\
\text { kendiri (mis. } \\
\text { Senarai } \\
\text { semak yang } \\
\text { dipribadi- } \\
\text { kan) }\end{array}$ \\
\hline $\begin{array}{l}\text { Tidak } \\
\text { terorgani- } \\
\text { sir }\end{array}$ & $\begin{array}{l}\text { Kehilangan } \\
\text { tugasan, lupa } \\
\text { kerja rumah, } \\
\text { tidak menye- } \\
\text { lesaikan } \\
\text { tugasan. }\end{array}$ & $\begin{array}{l}\text { Ajarkan } \\
\text { strategi } \\
\text { organisasi } \\
\text { (misalnya, } \\
\text { kalender, } \\
\text { buku catatan } \\
\text { pekerjaan } \\
\text { rumah) } \\
\text { Memeriksa } \\
\text { pekerjaan } \\
\text { rumah } \\
\text { secara } \\
\text { teratur, } \\
\text { meminta } \\
\text { orang tua } \\
\text { untuk } \\
\text { memeriksa } \\
\text { pekerjaan } \\
\text { rumah }\end{array}$ \\
\hline $\begin{array}{l}\text { Kesulitan } \\
\text { memperta- } \\
\text { hankan } \\
\text { perhatian }\end{array}$ & $\begin{array}{l}\text { Mengalami } \\
\text { kesulitan } \\
\text { mengikuti } \\
\text { tugasan } \\
\text { jangka } \\
\text { panjang. } \\
\text { Mengalami } \\
\text { kesulitan } \\
\text { memberi }\end{array}$ & $\begin{array}{l}\text { Pecahkan } \\
\text { proyek } \\
\text { jangka } \\
\text { waktu } \\
\text { panjang } \\
\text { menjadi } \\
\text { langkah- } \\
\text { langkah } \\
\text { yang dapat }\end{array}$ \\
\hline
\end{tabular}




\begin{tabular}{|l|l|l|}
\hline & perhatian & dikelola. \\
semasa kelas & Gunakan \\
dengan & pembelaja- \\
format & kuliah. \\
Mungkin & kooperatif. \\
& Dampingi \\
& kesulitan \\
untuk fokus & $\begin{array}{l}\text { prentasi } \\
\text { lisan dengan } \\
\text { visual. }\end{array}$ \\
\hline $\begin{array}{l}\text { Kinerja } \\
\text { yang tidak } \\
\text { konsisten }\end{array}$ & $\begin{array}{l}\text { Tugasan yang } \\
\text { sentiasa tidak } \\
\text { konsisten. } \\
\text { Mengulangi }\end{array}$ & $\begin{array}{l}\text { Menerima } \\
\text { variabilitas } \\
\text { dalam } \\
\text { kinerja } \\
\text { siswa. }\end{array}$ \\
& kesilapan \\
yang sama. & \\
\hline
\end{tabular}

\section{KESIMPULAN}

Strategi pembelajaran adalah caracara yang akan dipilih dan digunakan oleh seorang pengajar untuk menyampaikan materi pembelajaran yang bertujuan untuk memudahkan peserta didik menerima dan memahami materi pembelajaran, yang pada akhirnya tujuan pembelajaran dapat dikuasainya di akhir kegiatan belajar.

Tiga hal strategi pembelajaran yang efektif adalah: (1) Siswa Memerlukan Instruksi Strategi yang Berkelanjutan. (2) Guru Mempromosikan Kesadaran Diri dalam Metakognisi di Kelas. (3) Guru-guru Dapat Mengenali dan Memahami Profil Pembelajaran yang Berbeda.

Strategi Pembelajaran di antara Guru terhadap Siswa dalam Konteks Memecahkan Kesulitan Belajar adalah: (1) kesulitan belajar dimanifestasi dalam bilik kelas, (2) kesulitan didemonstrasi oleh siswa dalam bilik kelas, dan (3) strategi-strategi untuk membantu siswa yang kesulitan perhatian di kelas.

\section{DAFTAR PUSTAKA}

"Center for

Evaluation

Innovation",https://www.bsu.edu/ab out/administrativeoffices/online-andstrategic-learning/about (diakses pada 21/9/2020).

Brooks, Robert. "Islands of competence", https://massappleseed.org/wpcontent/uploads/2018/01/drbrooks_studentmindset_chapter.pdf.

Brown, A.L. Brown \& Campione, J.C. (1986), "Psychological Theory and the Study of Learning Disabilities". American Psychologist, 41(10), 1059-1068.

https://doi.org/10.1037/0003-

066X.41.10.1059.

Erlbaum, Lawrence. Research and Global Perspectives in Learning Disabilities. Mahwah NJ: Lawrence Erlbaum Associates Pub., 2001.

GP, Harianto. (2016), "Quality Learning Cooperative With Pattern Collaborative to Improve the Character", Jurnal Tekpen, 1(1), 43.

GP, Harianto. Pendidikan PAK. Yogyakarta: Andi, 2017.

https://www.researchgate.net/publication/50 313189_Strategic_Learning_and_Te aching (diakses pada 25/9/2020).

Schiff, Rachel Schiff dan Joshi, R. Malatesha (eds). Intervention in Learning Disabilities. AG Switzerland: Springer International Publishing, 2016.

Schumaker, J.B. \& Deshler, D.D. “Teaching Adolescents to be Strategic Learners". Teaching Adolescents with Disabilities: Accessing the General Education Curriculum. Thousand Oaks, CA: Corwin Press, 2006. 